\title{
Contested governance of drinking water provisioning services in Nepal's transboundary river basins
}

\begin{abstract}
Governance and management of ecosystem services involve a diversity of institutional mechanisms and policy processes from voluntary to regulatory and collaborative approaches. The governance structures and policy processes are often contested, particularly when stakeholder concerns are insufficiently addressed, particularly of those who are most affected by policy decisions. This research examines how collaborative governance enables the ecosystem services approach to source water protection, thereby addressing contested governance problems and policy processes in transboundary river basins in central Nepal. The data were collected using key informant interviews, policy workshops, policy document review, and direct observation. Research results suggest that the state established collaborative governance institutions to improve already adversarial situations rather than in the co-management of water provisioning and other ecosystem services. We conclude that collaborative governance should focus on empowering vulnerable communities to speak for themselves and for the natural environment, particularly to maintain the sustainable flow of multiple ecosystem services for current and future generations.
\end{abstract}

Keywords: ecosystem services; source water protection; river basins; Nepal; policy process

\section{Suggested citation:}

Bhattarai, Kiran Kumari, Pant, Laxmi and FitzGibbon, John (2020) Contested governance of drinking water provisioning services in Nepal's transboundary river basins. Ecosystem Services, 45. ISSN 2212-0416 (doi:https://doi.org/10.1016/j.ecoser.2020.101184) 


\section{Introduction}

Besides water-induced casualties, nearly 2.1 billion people worldwide lack access to safe drinking water, 4.5 billion lack adequate sanitation, and 2.2 million people die from water-related diseases every year (WHO, 2017). Contrary to this grim statistics, it was proclaimed that Target $\mathrm{C}$ of the seventh Millennium Development Goal (MDG7), which aimed to halve the proportion of people without access to improved sources of water, was met five years ahead of schedule in 2010 (MDG, 2013). Globally, while rural areas struggle to secure clean drinking water, sanitation and other livelihood needs, rapidly growing urban municipalities face challenges with an adequate supply of safe water and appropriate infrastructure (Brooks, 2002). In order to address growing water crises, urban areas draw additional water from the surrounding rural areas to compensate for the loss of urban ecosystem services. Although rural to urban water transfers are often seen as just and legitimate state interventions, restrictions on customary use and reduced flows in the river can cause injustices to rural communities and the environment. The benefits of water extraction are, for the most part, accrued in urban places where the raw water is processed in treatment plants to generate added value in the form of clean and safe water to support the 'flush and forget' consumer culture. Contrary to this anthropocentric view on the use of water resources, water is an important service the natural ecosystem provides, among others. The 2005 Millennium Ecosystem Assessment (MEA) identifies that water is an ecosystem service (with provisioning, regulating, cultural and supporting functions), and the need for responsible management of the finite supply of drinking water sources (MDG, 2013; MEA, 2005). As a follow up to the water related MDGs targets, the sixth Sustainable Development Goal (SDG 6) aims to ensure access to water and sanitation for all by 2030 (United Nations, 2015).

Stewardship of the environment and ecosystem services is normally left to the voluntary sector (Liarakou et al., 2011; Ryan et al., 2001), but it is often the case that regulations are also necessary, particularly when over extraction is imminent (EPA, 2009; Morrison et al., 2014). Besides selfmotivated volunteers, environmental stewards also include state regulators, such as park wardens and law enforcement officials, and collaborative governance measures, such as forest stewardship, marine stewardship and fair trade certification (Kreutzwiser et al., 2011; Richter, 2008). Furthermore, as neither regulative nor voluntary governance is sufficiently effective in managing 
ecosystem services, scholars suggest to opt in for the collaboration of state and non-state actors (Ananda et al., 2013; Ansell et al., 2008). Governance and management of ecosystem services entail a diversity of policy instruments, such as assessment and valuation of ecosystem services, but they are often controversial because different stakeholders could prioritize provisioning services (e.g., drinking water and food) and other serveries differently (Keune et al., 2015; Schleyer et al., 2015). Municipal water provisioning is often understood as a problem of physical water scarcity, which is rather a manifestation of inefficient management of ecosystem services (Sharp et al., 2011). Particularly in large-scale water diversion, it is a challenge to maintain environmental flow, which is the water regime provided within a river, wetland or coastal zone to sustain ecosystem health (Acreman, 2016; Dyson et al., 2003). Despite this fact, institutional aspects are insufficiently addressed in the development of water resources and infrastructures (Keune et al., 2015; Mann et al., 2015; Primmer et al., 2015). This research aims to addresses this gap by examining how collaborative governance and management enable the ecosystem services approach to source water protection in Nepal's transboundary river basins that provide drinking water for the Kathmandu Valley, the national capital and the largest city of 2.5 million human population. This research creates new knowledge in the science and practice of ecosystem services, which would lead to better policy decisions to empower vulnerable communities most affected by natural resource development in Nepal and similar contexts across the developing countries. However, the findings should be interpreted within the context that the entry points for this research were two most significant, and yet highly controversial, rural to urban water transfer projects in the country with time frames spanning over eight decades and limited availability of longitudinal data.

The next section first reviews the literature on governance and management of ecosystem services and develops a conceptual framework for the analysis of empirical data. Then we describe study areas, including the two most significant rural to urban water supply transfers - the largest existing source in Sundarijal and the largest ongoing project in Melamchi. This section ends with a description of the procedure to collect empirical data on drinking water provisioning services. Then, in Section 3, we present research results and analyze the findings on the governance and management of ecosystem services in transboundary river basins in Nepal. Section 4 discusses research findings using the conceptual framework in Section 2, and the final section concludes the 
paper with an emphasis on the collaborative empowerment of local communities to govern ecosystem services.

\section{Materials and methods}

\subsection{Governance and management of natural resources and ecosystem services}

Different modes of natural resource governance address uncertainty and complexity differently, which often results in questionable or controversial policy decisions. This body of literature represents a continuum of regulatory and voluntary approaches with various forms of collaborative approaches in between (Table 1).

Table 1. Theories of policy change.

\begin{tabular}{|c|c|c|c|c|}
\hline & \multicolumn{3}{|c|}{ Management approach } \\
\hline & & Regulatory & Collaborative & Voluntary \\
\hline \multirow{3}{*}{$\begin{array}{l}\text { Uncertainty, } \\
\text { complexity }\end{array}$} & Low & $\begin{array}{l}\text { Rational choice } \\
\text { (Homans, 1961) }\end{array}$ & $\begin{array}{l}\text { Institutional rational } \\
\text { choice(Kiser et al., 1982) }\end{array}$ & $\begin{array}{l}\text { Adaptive management } \\
\text { (Folke et al., 2005) }\end{array}$ \\
\hline & High & $\begin{array}{l}\text { The precautionary } \\
\text { principle (Cameron } \\
\text { et al., 1991) }\end{array}$ & $\begin{array}{l}\text { Advocacy } \\
\text { coalition(Sabatier et al., } \\
\text { 2007) }\end{array}$ & $\begin{array}{l}\text { Adaptive co- } \\
\text { management (Schultz et } \\
\text { al., 2011) }\end{array}$ \\
\hline & & & $\begin{array}{l}\text { Multiple governance (Hill } \\
\text { et al.. 2006) }\end{array}$ & \\
\hline
\end{tabular}

Source: Authors' compilation

\subsubsection{Regulatory governance}

Some form of state control, through market mechanisms or centralized economic planning, is common in many jurisdictions through measures, such as nationalization of forest areas, declaration of conservation areas, and government managed large-scale water transfer projects (Agrawal et al., 2007). People make rational decisions based on presumably complete information, such as costs and benefits of action (Homans, 1961). They, however, fail to recognize traditional or habitual action, emotional or effectual decisions, and various forms of the value-oriented acts because decisions are often made under incomplete information, including the limitations of human cognition, habitual actions, and deep cultural patterns (Goode, 1997; Scott, 2000). In other words, regulatory public policy-making fails to explain the origins of social norms and values, especially those of altruism, reciprocity and trust, to the problem of social norms (Funtowictz et al., 1993). This is why the rational choice theory suffers from its failure to explain why individuals 
join many kinds of groups, associations and networks to make a collective choice, the problem of collective action (Ostrom, 1998).

Under incomplete scientific evidence, the precautionary principle guides a decision, particularly when there are severe threats of irreversible or irreparable damage to human wellbeing and ecosystem services (Cameron et al., 1991; Summers et al., 2008). The threats of irreversible damage are used to justify additional precautions in the management of ecosystem services (Persson, 2016). However, decisions are only provisional because the precautionary principle is the least understood and often controversial decision tool (Foster et al., 2000). According to this principle, it would be a breach of the regulation when we fail to act on the grounds of scientific uncertainty alone (Faunce et al., 2008; Hornbaker et al., 2003; Marambio-Jones et al., 2010; Stewart, 2002).

\subsubsection{Voluntary governance}

Voluntary governance is a relatively recent initiative in the formal policy process although voluntarism has been known throughout human history. Voluntary actions are motivated by nonmaterial incentives, such as learning and contact with nature (Liarakou et al., 2011); a sense of belonging, caretaking the environment and personal learning (Bramston et al., 2011); and ego, altruism and concern for the biosphere (Schultz, 2001). Voluntary governance focuses on local adaptation to changes in social and ecological systems through self-organizing systems of governance (Asah et al., 2012). Adaptive management is one such science and practice of ecosystem services, which challenges the command and control approach of regulative governance (Dietz et al., 2003; Folke et al., 2005; Holling, 1978; Ryan et al., 2001; Stern et al., 2002). Adaptive management aims to enhance socio-ecological resilience, which reflects two different worldviews: engineering resilience and ecological resilience (Folke, 2006; Holling, 1996). While the former entails resilience as the ability of the system to return to the steady-state after a perturbation (Holling, 1978), the latter refers to the ability of a natural ecosystem to absorb disturbance before the system redefines its structure (Folke, 2006; Gallopin, 2006; Gunderson et al., 1995).

Particularly to address the complexity and uncertainty of natural resource management, the literature on adaptive co-management recognizes the importance of engaging vulnerable communities most affected by resource development, often in collaboration with the state agencies 
(Olsson et al., 2004; Schultz et al., 2011). However, adaptive co-management also faces challenges, such as effectively engaging multiple stakeholders, building trust, making systematic connections, motivating stewardship behaviours, and facilitating learning, innovation, and adaptation (Bramston et al., 2011; Clark et al., 2013; Kreutzwiser et al., 2011).

\subsubsection{Collaborative governance}

Questionable performance of regulatory governance often results in the reduction of state control opening up the opportunity for the participation of natural resource dependent communities in policy processes (Babel et al., 2011; Schultz et al., 2011). In recognition of this opportunity to engage affected communities, collaborative governance and management gained currency (Emerson et al., 2011; Ferreyra et al., 2008; Parkes et al., 2008). A comprehensive definition of collaborative governance includes the following five aspects (Gray et al., 2018). First, the actors are interdependent concerning a problem or an issue of natural resource management, and none of them can solve the problem on their own. Second, collaboration is an emergent process that uses shared rules, norms and structures. Third, it involves constructively wrestling with a difference using formal and informal negotiations and consensus-building to find trade-offs that create value for all stakeholders. Fourth, stakeholders bring different competencies and need to respect and learn from each other's expertise. Finally, stakeholders assume joint risk and responsibility for the outcome of their joint efforts. Himmelman (2001) differentiates the aim of collaboration into collaborative betterment and collaborative empowerment, and the latter is more about the building capacity of vulnerable communities affected by resource development to produce intended results.

\subsection{Conceptual framework for empirical data analysis}

In this section, we discuss five challenges of the collaborative governance of environment and ecosystem services, which will guide the analysis of research results (Table 2). The challenges are failure to acknowledge complexity, hierarchical social space, the interdependence of management problems in space, time and scale, lack of trust and commitment among stakeholders, and conflict arising from miscommunication (Booher, 2005; Booher et al., 2010; Innes et al., 2011; Richter, 2008). 
Table 2. Management challenges and related propositions for collaborative governance.

\begin{tabular}{|c|c|c|}
\hline Challenges & Propositions for collaborative governance* & Empirical examples** \\
\hline $\begin{array}{l}\text { Complexity and } \\
\text { uncertainty }\end{array}$ & $\begin{array}{l}\text { Collaborative governance enhances the economy } \\
\text { of scale when independent actors are less likely to } \\
\text { deliver ecosystem products or services. } \\
\text { Collaborative governance reduces transaction costs } \\
\text { as it minimizes points of contact with affected } \\
\text { communities. }\end{array}$ & $\begin{array}{l}\text { Focus on infrastructure development } \\
\text { and technology transfer. } \\
\text { Community engagement through } \\
\text { social upliftment programmes only at } \\
\text { later stages of the project. }\end{array}$ \\
\hline $\begin{array}{l}\text { Hierarchical social } \\
\text { space }\end{array}$ & $\begin{array}{l}\text { Collaborative governance helps federal or state- } \\
\text { level agencies to design better policies or programs } \\
\text { with local or regional governments that require } \\
\text { localized actions. } \\
\text { Collaboration with federal or state agencies builds } \\
\text { local or regional capacity or provides access to } \\
\text { resources. }\end{array}$ & $\begin{array}{l}\text { Centralized, predictive planning and } \\
\text { implementation of rural to urban } \\
\text { water transfer projects. } \\
\text { Building local or regional capacity a } \\
\text { missed opportunity. }\end{array}$ \\
\hline $\begin{array}{l}\text { Interdependence of } \\
\text { management } \\
\text { problems }\end{array}$ & $\begin{array}{l}\text { Collaborative governance is effective to solve } \\
\text { interdependent natural resource management } \\
\text { problems when stakeholders do not already } \\
\text { participate in other collaborative venues and/or } \\
\text { they have a weak social capital. } \\
\text { Collaboration with organizations active in other } \\
\text { sectors is preferred when natural resource } \\
\text { managers are constrained to act within one policy } \\
\text { sector, but they face a problem that spans multiple } \\
\text { sectors (e.g., food, water, sanitation). }\end{array}$ & $\begin{array}{l}\text { Governance of multiple ecosystem } \\
\text { services in transboundary river } \\
\text { basins. } \\
\text { Include multiple policy sub-sectors: } \\
\text { water, sanitation, hygiene, food, } \\
\text { agriculture, natural resources, urban } \\
\text { farming, food forests, urban forests, } \\
\text { and conservation of the holy rivers } \\
\text { and the UNESCO World Heritage } \\
\text { Sites and farmland. }\end{array}$ \\
\hline $\begin{array}{l}\text { Trust and } \\
\text { commitment among } \\
\text { stakeholders }\end{array}$ & $\begin{array}{l}\text { Collaboration with parties directly affected by } \\
\text { proposed actions is likely to be effective when } \\
\text { natural resource managers perceive that the } \\
\text { legitimacy of their organization is low. } \\
\text { Collaboration with well-reputed actors is likely to } \\
\text { happen when natural resource managers perceive a } \\
\text { low legitimacy of their organization. }\end{array}$ & $\begin{array}{l}\text { The state collaborated with affected } \\
\text { communities, action groups and non- } \\
\text { governmental organizations to } \\
\text { transform adversarial relationships. } \\
\text { The Melamchi Water Supply project } \\
\text { sought an opportunity to collaborate } \\
\text { with non-governmental organizations } \\
\text { to placate the protests. }\end{array}$ \\
\hline $\begin{array}{l}\text { Miscommunication, } \\
\text { controversy and } \\
\text { conflict }\end{array}$ & $\begin{array}{l}\text { Collaborative governance is likely to be more } \\
\text { effective when the perceived costs of controversy, } \\
\text { contentions and litigations are higher than the costs } \\
\text { involved in a collaboration. } \\
\text { Natural resource managers are more likely to } \\
\text { collaborate when they are worried about the loss of } \\
\text { power and influence rather than joint gains. }\end{array}$ & $\begin{array}{l}\text { Civil society organizations and local } \\
\text { communities were initially seen as } \\
\text { contingent to the success of the } \\
\text { project } \\
\text { A transformation from contingent to } \\
\text { necessary collaboration for effective } \\
\text { management of ecosystem services }\end{array}$ \\
\hline
\end{tabular}

Note:

*Propositions adapted from Scott et al. (2017).

**The empirical examples are elaborated in the Results section and subsequently discussed in the Discussion section.

First, regulatory governance often does not properly recognize the complexity resulting in unintended, and sometimes perverse, consequences of large-scale planning and centralized, 
hierarchical command and control management (Booher, 2005; Booher et al., 2010; Innes et al., 2018). The unintended impacts of well-meaning centralized planning include the simplification of complex issues as if the cause and effect relationships are evident, which subsequently results in poor policy outcomes (Scott et al., 2017). Complex systems are characterized by a high level of uncertainty and a low level of agreement among stakeholders (Stacey, 2002). Collaborative governance aims to diversify issues, improve the quality of policy outcomes, reduces the point of contact for service providers to reduce per unit cost of services (Scott et al., 2017). A low level of stakeholder agreement in complex systems provides a space for argumentation and debate (Hinsch, 2010). However, if stakeholders fail to use this as an argumentative space safe enough for their value proposition, collaborative governance will simply perpetuate the liberal principle of justice as a moral virtue of political systems. What is important is to complement the moral virtue of political systems with the political virtue of legitimacy, questioning the very purpose of nonargumentative and hierarchical stakeholder participation (Sleat, 2015).

Second, each level of government has its areas of authority and responsibility, both geographically and substantively (Booher, 2005). Geographically, the local fits within the regional, regional, within state, and state within national. These areas of authority are often carried out through hierarchical, command-and-control governance thereby limiting the opportunity to augment the quality of traditional non-argumentative decision making. As an alternative, collaborative governance aims to bridge hierarchies of local, regional, state and federal agencies (Margerum, 2011; Scott et al., 2017).

Third, decision making in complex and diverse natural resource management problems are interdependent. When traditional natural resource management agencies alone cannot solve complex and interdependent problems, collaborative decision making would more effectively facilitate work across places, spaces, scales, and policy sectors (Booher, 2005). Particularly when a need is required to collaborate with public interest groups, natural resource managers should distinguish collaborative governance from more casual and conventional forms of nonargumentative interaction (Ansell et al., 2008; Freeman, 2010). If collaborative governance is described as informal relationships that agencies and interest groups cultivate, it would merely perpetuate the liberal principle of justice as the virtue of political systems (Sleat, 2015). Ansell and Gash (2008) further suggest that collaborative governance as, for some natural resource managers, 
can imply public-private partnership, which typically requires collaboration to function, but their goal is often to achieve coordination.

Fourth, addressing complex natural resource management problems involves a great deal of time, trust and commitment among stakeholders to avoid a power struggle, miscommunication and conflict (Himmelman, 2001). For traditional top-down regulatory governance, trust and confidence on the part of the public originate from deep core beliefs at the constitutional level and policy core belief at the directional level (Beetham, 1991; Booher, 2005). Trust cannot be assumed in collaborative governance that requires managers to collaborate across institutional boundaries.

The fifth and final challenge is that collaborative governance can become culturally diverse and would require to include traditionally excluded stakeholders. The problem of mistrust, conflict and miscommunication could be intimidating as natural resource managers are increasingly required to deal with an array of the public with their languages, values, perspectives, cognitive styles, and worldviews (Booher, 2005). Thus, deliberation, or reasoned communication, is recognized as a hallmark and essential ingredient of transforming conflict into creativity (Emerson et al., 2011). In collaborative governance, stakeholders would often have an adversarial relationship to one another, but the goal is to transform adversarial relationships into more cooperative or empowering ones (Ansell et al., 2008; Himmelman, 2001). The five theoretical propositions discussed above inform about when and why collaborative governance is useful to govern and manage ecosystem services (Emerson et al., 2015; Scott et al., 2017).

\subsection{Study Areas}

This study was conducted in the context of Nepal's two most significant rural to urban water transfers for municipal use in the Kathmandu Valley: the existing intrabasin water source in Sundarijal and the ongoing interbasin water transfer project in Melamchi.

\subsubsection{Sundarijal Water Supply System}

The Sundarijal water source lies in the Gokarneswor Municipality within the Bagmati River Basin. The source of the Sundarijal Water Supply System originates from the Shivapuri Nagarjun National Park and provides about 30 mld water to the Kathmandu Valley's municipal water supply. If source water protection practices are effectively implemented by providing incentives to local communities, it has the potential of generating additional 75 mld water (Maskey, 2008). As a 
regulatory measure to conserve the source water, a protected watershed area declared in 1976, later upgraded into a wildlife reserve in 1985 and finally as a highland national park in 2002. The upstream villages in this area predominantly inhabited by Indigenous Tamang communities occur within the national park and the buffer zone, which serves as a strategic zone requiring protection to supply drinking water to the national capital of Nepal. Total protection has provided through formulated programme activities of massive plantation and reforestation to minimize further degradation of the fragile hill slopes which had been deforested, cultivated and grazed (Babel et al., 2011; Shrestha, 1998). According to the recent annual report of the Shivapuri Nagarjun National Park (2017), there were 1700 Nepalese Army officers and 51 civilian staff responsible for the management of ecosystem services in the park.

\subsubsection{Melamchi Water Supply Project}

The Government of Nepal has proposed a large-scale drinking water supply transfer project called the Melamchi Water Supply Project to resolve water crises in the Kathmandu Valley (Figure 2). This project is designed to meet the long-term (over 30-40 years) water demand in the Kathmandu Valley (located in the Bagmati River basin) by diverting water from the Melamchi River located in Indrawati River basin (part of the Koshi River Basin) $40 \mathrm{~km}$ northeast of Kathmandu (Pant et al., 2008). The Melamchi Water Supply Project diverts water from an arguably water-abundant rural setting to a water-scarce urban area in the Kathmandu Valley through the construction of a $27 \mathrm{~km}$ tunnel across the fragile mountain range (Domènech et al., 2013; Pant et al., 2008). The Melamchi water source lies in the Langtang National Park, which was also established in 1976 (Borradaile et al., 1977). Several villages, mostly the Hyolmo communities, are located within the park and the buffer zone. They depend on natural resources for much of their livelihoods, such as grazing livestock within designated areas, collecting grass, fodder, fuelwood and construction timber at low cost (Fox et al., 1996).

All major rivers and tributaries in the Bagmati River Basin, where the Kathmandu Valley lies, are fed by monsoon rains. In contrast, the Melamchi River in the Indrawati River Basin is fed by rain, snow, and glacier melt. High seasonal variability in rainfall is also a part of the problem in Nepal's drinking water supply as about 80 percent of monsoon rain falls from June to August. Climate change can further disrupt ecosystem services in these basins. A recent assessment warns that if global warming continues, at least one-third of Himalayan glaciers could melt by the end of this 
century disrupting the flow of water and other ecosystem services for over two billion people in Asia (Wester et al., 2019). The Himalayan National Park Regulations, 1976 granted local residents within the national park and the buffer zone limited use of park resources (Bhattarai et al., 2017). Scholars and practitioners have recommended the Payment for Environmental Services (PES) provided by local residents, which is a market-led mechanism to motivate source water protection by those residing within the park and in the buffer zone (Kunwar, 2008; Maskey, 2008; Pant et al., 2013). In 1993, the National Parks and Wildlife Conservation Act amended for the fourth time to include the provision of buffer zone management, which provides a legal provision to allocate 30 to 50 percent of park revenue for community development programmes (Bhattarai et al., 2017; Peh et al., 2016). However, a policy maker familiar with the Shivapuri Nagarjun National Park told that revenue from the park is not even enough for the regular park maintenance, let alone payment of ecosystem services. 


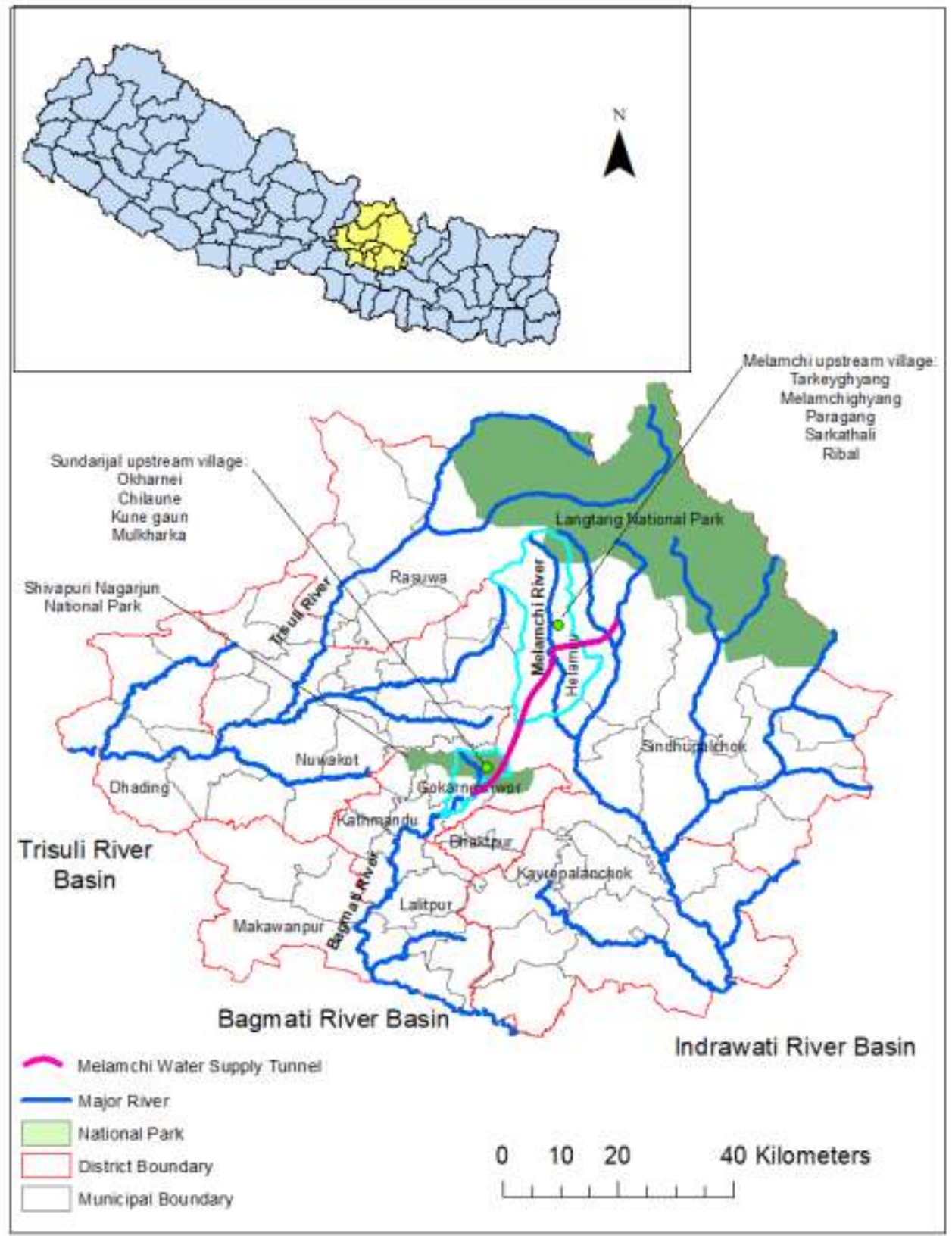

Figure 1. Study area showing existing and ongoing municipal water transfer systems for the Kathmandu Valley.

Note:

The Melamchi Water Supply Tunnel $(27 \mathrm{~km})$ is proposed to transfer water from the Melamchi River in the Indrawati River Basin to the Kathmandu Valley (Bhaktapur, Kathmandu, and Lalitpur districts) in the Bagmati River Basin. In the second and third phases of the project, this tunnel will transfer water from two additional rivers in the Indrawati River Basin. 


\subsection{Data collection procedure}

This research employs a case study approach to examine current and future source water protection measures to supply safe and adequate drinking water while promoting already vulnerable rural livelihoods. The empirical data were collected from November 2015 to February 2016, followed by a short follow-up field visit from December 2016 to January 2017. This was the time when Nepal went through multiple vulnerabilities - the immediate aftermath of the 2015 Gorkha Earthquake, broader blockade with India, and transition to the federal restructuring of governance structures and policy processes. This paper is part of a larger mixed methods case study and primarily based on the review of 34 policy document reviews, 40 key informant interviews, two policy workshops, and direct observation on various occasions. The intention was to interrogate different perspectives on the central phenomenon or key concept of water provisioning services (Creswell et al., 2018).

The sampling of policy documents was purposive and remained iterative throughout the research process. In most cases, key informants spontaneously suggested relevant documents to refer to, for additional information on some specific topics. Some respondents generously provided hard copies or a link to electronic copies of policy documents that they thought would be relevant. Altogether, the policy documents identified include 18 acts and regulations, and 16 documents on strategies, plans and policy. Although most of them were available in an electronic format, a few documents were available only in hard copies. Some of them were only available in the Nepali language. The coding of these documents was done manually by the first author, who speak the local language Nepali so that we were able to include the hard copies in the analysis and the Nepali language documents without translation. Policy workshops were held on two different occasions. The first policy workshop was held at the inception of the fieldwork to identify relevant policy issues and to solicit suggestions for the effective implementation of field research. The second policy workshop involved a discussion on preliminary research results.

A total of $40 \mathrm{key}$ informant interviews were conducted, which took 1 to 2.5 hours each. The identification of key informants began with the prominent people, which led to sampling widely across Nepal's Water, Sanitation and Hygiene (WASH) sector to the degree that we were confident that we had spoken to the majority of the decision makers. We used a purposive snowball sample 
stratified by seven stakeholder groups - local communities, civil society actors, public policy makers, research scientists, service providers, donors, and contractor (Figure 2). Initial contacts were identified from the project documents and in consultation with the local host organizations. The persons recommended by initial contacts were interviewed, and they were asked for additional key informants. This process continued until all stakeholder groups were represented, and saturation was reached with no new information being generated. The interviews were audiorecorded with the permission of the interviewees, and transcribed into Nepali, and translated into English for analysis. Then, the interview transcripts were imported into the qualitative data analysis software NVivo. v. 11. A decision was made to merge the civil societies and local communities into one category of stakeholders as they had a common interest to serve affected communities and donors and contractors also kept in one category. The number of respondents from the five stakeholder groups was $15,10,8,4$, and 3, respectively civil society actors, public policy makers, researchers, service providers, and donors. A coding framework was developed for data analysis, which included a priori axial codes from the literature as well as open codes generated through repeated reading of the interview transcripts. 


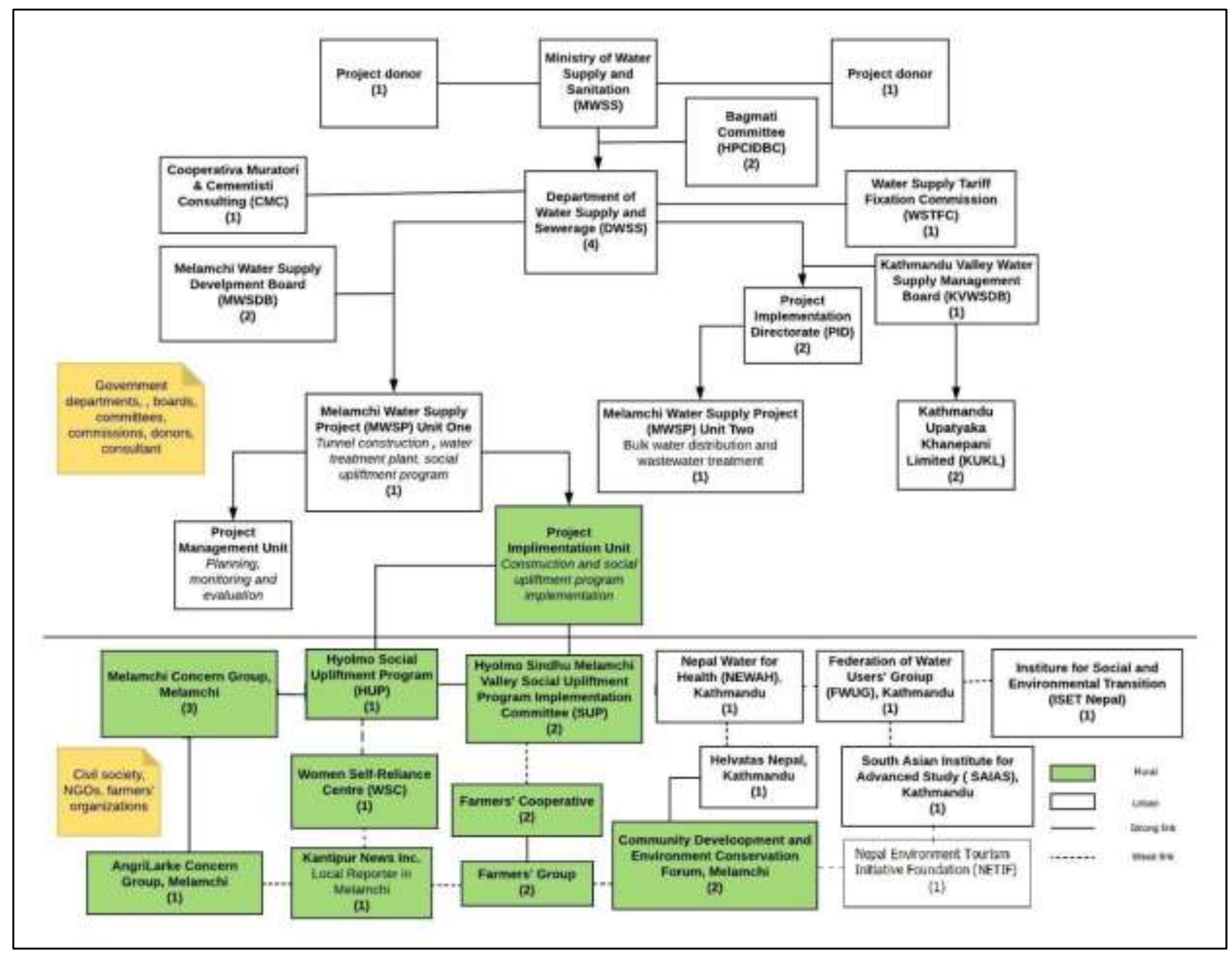

Figure 2. Stakeholder organization of the municipal water supply systems

Note: The number of key informants from respective organizations is indicated in the parentheses together with their organizational affiliation. The horizontal line separates dominant and minority stakeholders.

The most significant sites of observation are the two rural water sources and water treatment plants. The first author visited the source of the Sundarijal Water Supply System, which is $12 \mathrm{~km}$ east of the downtown of Kathmandu. She also visited the Shivapuri Nagarjun National Park, where the water source lies. The upstream communities, who are mostly Indigenous, follow subsistence farming, run small businesses, and have only basic water and sanitation facilities. The researcher also visited the Melamchi Valley in the Indrawati River Basin on five occasions and observed the water diversion site in the Melamchi River at Ambathan and the access to water and sanitation facilities in the local communities. These visits were held from November to February when mountains were supposed to be covered by snow. According to local elders, it was unusual to see 
bare mountains during this time of the year and they believed that it was because of climate change. Another observation of interest was the existing and new water treatment plants in Sundarijal in the Bagmati River Basin. The existing treatment plant was constructed in the mid-twentieth century and a new treatment plant of 85 mld capacity to treat the water from the Melamchi Water Supply Project. The direct observation method was also used to listen and collect the perspectives of the broader citizenry, such as taxi drivers, farmers, small business holders and scientists in both the source and receiving basins because the controversy about water provisioning services has become a long standing interest for the public.

\section{Results}

\subsection{Dwindling ecosystem services}

Key informants shared the belief that the Kathmandu Valley thrived on traditional systems of water management until the arrival of modernity, together with rapid population growth and urbanization. An interview with a water scientist revealed that the water and sanitation services of the valley used to be supported by royal canals (rajkulos) and stone spouts (dhunge dharas). Royal canals that used to transfer water from various sources from the outskirts of the valley to the urban core regularly recharged the stone spouts while also irrigating crops. In recent decades, the Kathmandu Valley has faced water scarcity. Municipal water supplies are available few hours only on a few days of a week. Those who can afford pump water from the municipal supply lines or private wells, turn to private water tankers, and buy bottled water to meet their ongoing water needs. Key informant interviews and direct observation revealed that many households in the valley build an underground water storage tank and fill it either from tanker water or whenever municipal is supplied. Urban poor, who cannot afford to build private infrastructures, such as wells and underground tanks, will not have water if they miss the moment the water is available from the municipal taps forcing them to go to polluted creeks and rivers to fetch water.

In Sundarijal, there was a provision of leaving more than 20 percent flows in the river than the amount of customary use as required by the Drinking Water and Sanitation Regulation (2016) to avoid adverse environmental impacts. However, enforcement of this regulation was challenging particularly in the face of the dwindling quantity of water at the source and increasing demand in the Kathmandu Valley. Seasonal variation should have to be considered because the Sundarijal 
water source is fed by monsoon rain. An analysis of the trend from 1980 to 2009 shows that the pre-monsoon rain increased, but the post-monsoon rain increased with subsequent impacts on river discharge (Dhital et al., 2013). An estimate shows that average discharge at the Sundarijal diversion site is $164 \mathrm{mld}$ and 30 percent of which is diverted by the Kathmandu Upatyaka Khanepani Limited (KUKL) to feed into the municipal water supply system of the Kathmandu Valley (KUKL, 2016; SNNP, nd). The remaining water is either diverted locally by various water users' groups and individual households or left in the river to maintain environmental flow for flora and fauna, including wild mammals in the Shivapuri Nagarjun National Park. Reliable estimates of neither customary use nor environmental flow estimates are available for the tributaries of the Bagmati River. A key informant summarizes the situation as follows based on his knowledge of the prevailing regulation that requires to leave at least 20 percent additional water than what has been customarily used:

In Sundarijal, we left more than 20 percent flows in the river [ in the beginning]. Nevertheless, we keep diverting the same amount of water over the last 50 years despite the decrease in water flow in the river. As a result, the environmental flow in the Bagmati River has been significantly decreased. (Respondent 26, policy maker)

The government of Nepal turned its attention to inter-basin water transfer attributing the 'system failure' to the unprecedented population growth and unplanned urbanization in the city, resulting significantly from the internal displacement of rural residents during the decade-long Maoist insurgency (1996-2006). Contrary to this dominant belief, interviews with key informants revealed that rather than effectively managing ecosystem services in the recipient basin, the state legitimatized their decision to invest in large-scale inter-basin projects, which has drained aid money disproportionately affect lives and livelihoods of more vulnerable communities in the country (Table 3). The deteriorating urban ecosystem services put undue pressure on rural ecosystems as we have seen from the rural to the urban transfer of resources, such as water, food, herbs, and timber. The increasing loss of urban ecosystem services in the Kathmandu Valley are compensated by the transfer of services from nearby rural ecosystems. Regulating services include filtration of pollutants, assimilation of solid wastes, purification of wastewater, insect pollination of crops and carbon sequestration in biomass and soil. Excessive human pressure on natural water bodies in the Kathmandu Valley deteriorated the urban ecosystem services turning the holy rivers, Bagmati and Bishnumati and their tributaries, into open sewers. Key informants described that modernization of urban landscapes for economic benefits also destroyed cultural services, such as 
the values of the holy rivers, the Pashupatinath Temple, Swayambhuna Temple and other UNESCO World Heritage Sites.

The loss of the urban ecosystem services impacted not only the provisioning, regulation and cultural services but also supporting services, such as the reduction in organic biomass production, disruption of biogeochemical cycles, disruption of the natural flow of floodwater, soil erosion, biodiversity loss and ecological vulnerability. As iterated by one of the policy workshop participants, livelihood related activities of the upstream rural communities can also pollute source water, which remained as a silent agenda for dominant stakeholders. Local and Indigenous Hyolmo communities were worried that the project could not only limit the supply of water for them, but it can also put restrictions on their livelihood activities as measures of source water protection. The Indigenous Tamang communities in Sundarijal have already experienced this aspect of vulnerability. Concerns were also expressed that the Melamchi Water Supply Project would aggravate the drying up of spring water sources, and also create mental health problems from the fear of relocation from ancestral land and the loss of opportunity to worship their rivers and cremate dead bodies on riverbanks.

Table 3. Deteriorating ecosystem services in the Kathmandu Valley puts pressure on rural areas

\begin{tabular}{|c|c|c|c|}
\hline $\begin{array}{l}\text { Ecosystem } \\
\text { services }\end{array}$ & Sundarijal & Melamchi & Kathmandu Valley \\
\hline \multirow[t]{3}{*}{ Provisioning } & Source water (+) & Source water $(+)$ & Water quality (-) \\
\hline & Food production $(+)$ & Food production $(+)$ & Source water (-) \\
\hline & $\begin{array}{l}\text { Firewood, fodder timber, } \\
\text { herbs }(+/-)\end{array}$ & $\begin{array}{l}\text { Firewood, fodder, timber, } \\
\text { herbs }(+/-)\end{array}$ & Urban food (-) \\
\hline \multirow[t]{4}{*}{ Regulating } & Carbon sequestration, & Carbon sequestration, & Loss of urban forest, pollinators (-) \\
\hline & pollination $(+)$ & pollination $(+)$ & Encroachment of wetland, flood (-) \\
\hline & Filtration of pollutants $(+)$ & Filtration of pollutants $(+)$ & Rivers/creeks turned sewers (-) \\
\hline & $\begin{array}{l}\text { Water purification, waste } \\
\text { assimilation }(+)\end{array}$ & $\begin{array}{l}\text { Water purification, waste } \\
\text { assimilation }(+)\end{array}$ & \\
\hline \multirow[t]{2}{*}{ Cultural } & Spiritual/aesthetic $(+)$ & Spiritual/aesthetic (+) & Spiritual/aesthetic (+/-) \\
\hline & Tourism/sense of place $(+)$ & Tourism/sense of place $(+)$ & Tourism/sense of place $(+/-)$ \\
\hline \multirow[t]{2}{*}{ Supporting } & Soil erosion (-) & Soil erosion (-) & Nutrition pollution (-) \\
\hline & Biodiversity (+) & Biodiversity $(+)$ & Biodiversity loss (- \\
\hline
\end{tabular}

Note: (-) Deteriorating ecosystem services, (+) Functioning ecosystem services, (+/-) Ecosystem services either at risk or face stringent regulation. The four categories of ecosystem services are adopted from the MEA (2005) 


\subsection{Deteriorating water provisioning services}

Direct observation showed that one of the sources of pollution in the Bagmati River and its tributaries is the direct discharge of solid waste and liquid wastewater into the river beyond the capacity of waste assimilation. Among the five major wastewater treatment plants that were constructed during the last four decades, only one was working, albeit partially, at the time of fieldwork. An emerging issue is that wastewater from industries, public and private hospitals and households are usually discharged into the already polluted water bodies without proper treatment. Only in 2009, the High Powered Committee for Integrated Development of the Bagmati Civilization (HPCIDBC) was established as a river basin agency to implement source water protection programs in the Bagmati River Basin. The primary goal of this committee is to conserve tributaries of the Bagmati River.

A respondent from the river basin agency stated that they aim to facilitate various watershed management activities. Although these activities were coordinated by this agency, the implementation was primarily a top-down decision to construct a trunk sewer pipeline along both banks of the river, development of a secondary sewer pipeline, rehabilitation of wastewater treatment plants, river training works, greenbelts along the bank of the river, and public awareness programs. For example, the communities upstream of Gokarna will receive a rainwater harvesting system to enhance the water level in the Bagmati River during the dry season. In an interview, a policy maker mentioned that the Bagmati River Basin Improvement Project was in the process of constructing two dams on the Bagmati River to regulate flow. They are a $19 \mathrm{~m}$ high Dhap Dam in Nagmati headwaters and 60 to $70 \mathrm{~m}$ high Nagmati Dam close to Chisapani, in the Shivapuri Nagarjun National Park. These dams will respectively store 800 thousand cubic metres of water, sufficient to provide a dry season environmental flow of 40 litres per second, and 8 million cubic metres of water, sufficient to provide a dry season environmental flow of 400 litres per second (ADB, 2013). As of September 5, 2019, a bidding process has been initiated to find contractors for an estimated cost of UD\$1.3 m (GoN, 2019).

A review of project documents and key informant interviews indicate that a local advocacy organization, the Melamchi Concern Group, was concerned about water reallocation, which could have long-term impacts on the deterioration of ecosystem services in the Melamchi Valley. As 
indicated in the Environmental Management Plan, the Melamchi Water Supply Project will maintain 0.4 cubic metres of water per second in the Melamchi River, which is less than 20 percent of the estimated average flow of 2.37 cubic metres of water per second in the river (Khadka et al., 2008). The legitimacy of this provision is questionable because the Drinking Water and Sanitation Regulation (2016) requires water transfer projects, small or large, to leave 20 percent additional water on the amount of customary use or a minimum amount to avoid adverse environmental impacts. Stakeholders of the Melamchi Water Supply Project demanded a levy from KUKL, the only formal water and sanitation service provider in the Kathmandu Valley. Although a resident recalled talk about sharing 1 to 2 percent of revenue from the sale of water in the Kathmandu Valley, he was worried that there had been no formal legislation about this provision until the time of this interview. Another resident summarized the legal challenges of revenue sharing as follows:

I understand that to determine levy, there should be a talk at the policy level. They need regulations to determine levy in this type of drinking water project. Then they should approve the regulation from the parliament. We understand that this could take a longer time to complete the policy-making process. However, this process has not been initiated. I am afraid that by the time they initiate this process, the project may already be completed. Community dialogues are there about the levy, but they don't have a basis to come to a figure. (Respondent 10, civil society)

\subsection{Increasing demand for water provisioning services}

Over the last century, the population in the Kathmandu Valley increased from under a half-million to 2.5 million in 2011, according to the latest available population census. Unofficial estimates are as high as four million, which far exceed the figure from the latest census because the national capital has become a transit hub for people who work across the country and also travel abroad for migrant work. In recent decades, the population increase in the Kathmandu Valley combined with unplanned and inadequate water and sanitation infrastructure development have made once viable, relatively smaller, intra-basin water transfer systems seemingly inadequate to support the increasing water demands. The earthquake in the spring of 2015 further aggravated the situation of the already poor water and sanitation infrastructure in the capital city. The current water demand in the Kathmandu Valley is about 366 mld (million litres per day) and the combined supply of groundwater and surface water (in the dry season) varies between 65 and $85 \mathrm{mld}$ and in the wet season between 140 to 144 mld (Bhattarai et al., 2005; KUKL, 2016). Thus, the available supply leaves more than half of the municipal water demand unfulfilled during the wet season. 


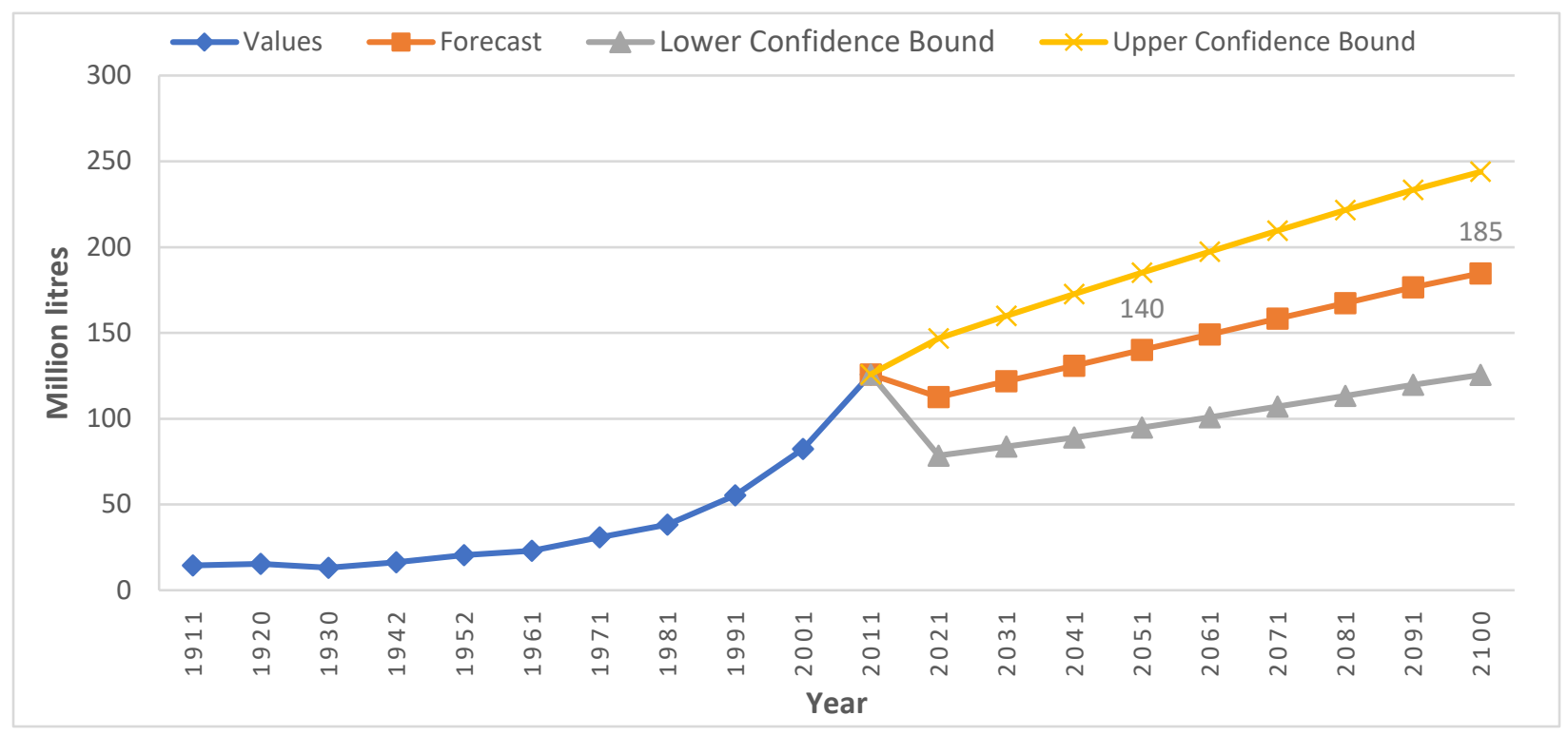

(a)

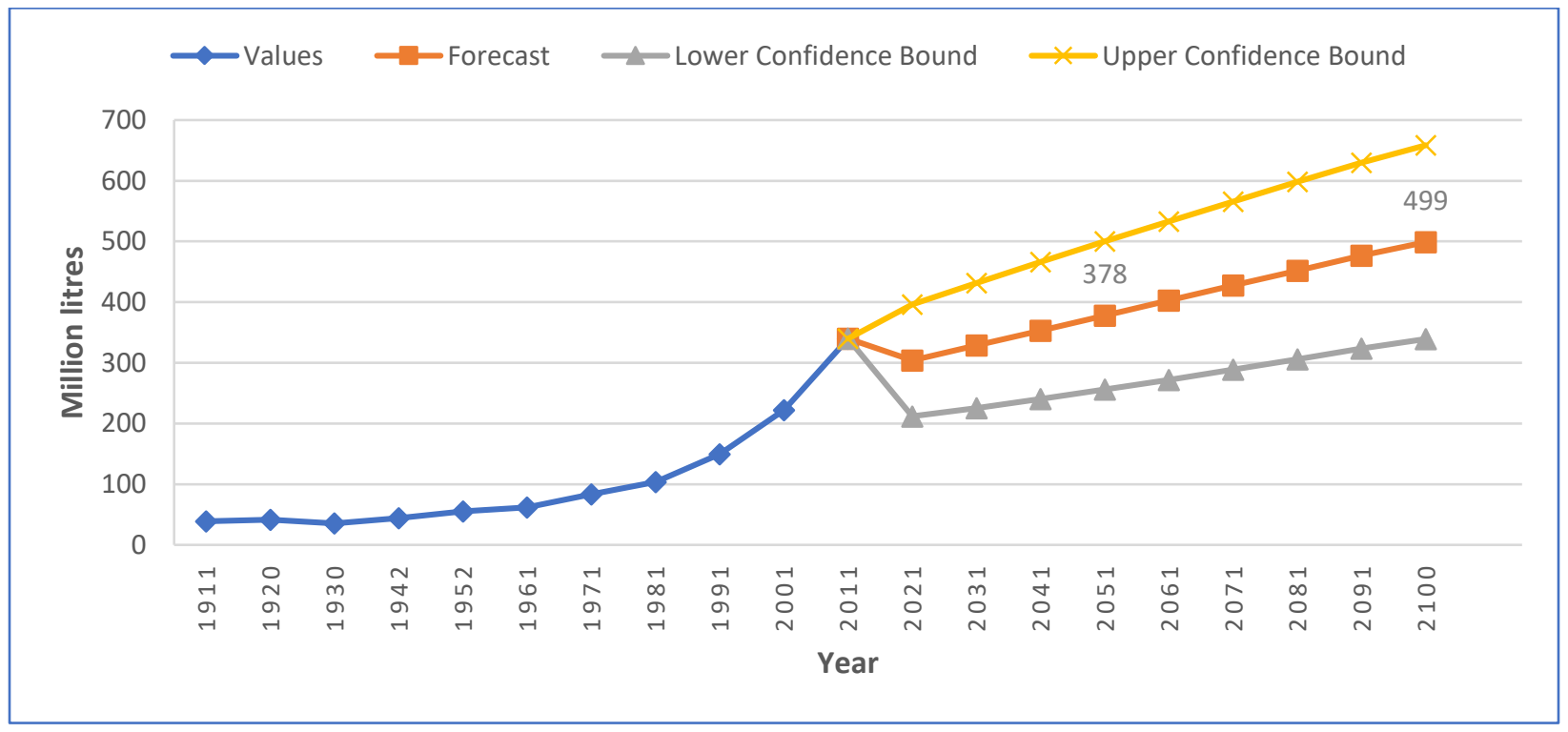

(b)

Figure 3. Projected water demand in the Kathmandu Valley. Source: Authors' estimates with reference to CBS (2014). Note: Figure 3 (a) water demand based on 50 litres per capita per day (United Nations standards for domestic use), and Figure 3 (b) water demand based on 135 litres per capita per day (Nepal Government standards for domestic and industrial use). 
Using an exponential smoothing function (ETS) to project population growth shows that by 2050 the population of Kathmandu Valley will be estimated at 2.8 million. By the end of this century, the population will be 3.7 million. According to the United Nations, for basic household use, the per capita water requirement is 50 litres per day, and the government of Nepal estimates that for domestic as well as industrial use, the per capita water requirement is 135 litres per day. Using these two standards, by the end of the century, the estimated water demands for the Kathmandu Valley are $185 \mathrm{mld}$ (Figure 3a) and $499 \mathrm{mld}$ (Figure 3b). These estimates have used population data since 1911. Similarly, medium-term estimates for these two standards are respectively 140 mld and 378 mld. However, a short-term forecast to 2021 using population data since 2001 shows a much higher water demand: $481 \mathrm{mld}$ and $541 \mathrm{mld}$, respectively, for 50 litres and 135 litres per capita per day requirements (Udmale et al., 2016).

\section{Discussion}

This section discusses the research results using the five challenges of natural resource management identified in the conceptual framework (Table 2), specifically about how collaborative governance could enhance water provisioning services in the transboundary river basins.

\subsection{Complexity and uncertainty of ecosystem services management problems}

In order to solve complex management problems, centralized predictive planning should be complemented by alternative planning approaches, such as visioning, adaptive co-management, and transformational collaboration (Linnenluecke et al., 2017). Transforming power structures in the governance and management of ecosystem services is challenging because there could be a diversity of power centres, resulting in a governance problem of polycentricity (Ostrom, 2010). The unintended impacts of well-meaning centralized planning include the simplification of complex issues as if the cause and effect relationships are clear, resulting in a poor quality of policy outcomes (Scott et al., 2017). Complex systems are characterized by high levels of uncertainty and low levels of stakeholder agreement on controversial issues (Stacey, 2002). The specific situations in the two water supply transfer projects of this study can be classified into four categories along two dimensions: certainty and agreement (Table 3). First, potential relocation of upstream Hyolmo 
communities, which has already been resisted. This issue is far from an agreement among relevant stakeholders, and the ultimate policy decision is still uncertain.

Table 3. Management decisions in Sundarijal and Melamchi Water Supply Projects. Source: The two-way matric is adapted from Stacey (2002)

\begin{tabular}{|c|c|c|}
\hline & Close to certainty & Far from certainty \\
\hline Far from agreement & $\begin{array}{l}\text { 3. Disagreement, certainty } \\
\text { Location of water diversion site }\end{array}$ & $\begin{array}{l}\text { 1. Disagreement, uncertainty } \\
\text { Relocation of upstream communities }\end{array}$ \\
\hline Close to agreement & $\begin{array}{l}\text { 2. Agreement, certainty } \\
\text { Water diversion } \\
\text { Construction of treatment plants } \\
\text { Monitoring water quality and safety }\end{array}$ & $\begin{array}{l}\text { 4. Agreement, uncertainty } \\
\text { Levy on water transfer, payment of } \\
\text { environmental services } \\
\text { Supply of adequate and safe water } \\
\text { Effectiveness of water treatment plants } \\
\text { Water allocation }\end{array}$ \\
\hline
\end{tabular}

Second, many policy decisions on the two rural to urban water transfer projects that are close to an agreement and certain to happen are highly technical. They include water diversion, bulk water distribution, construction of treatment plants, monitoring of water quality and safety, increasing block tariff and direct metering. These technical interventions to govern water provisioning services are influenced by the high modern development paradigm that involves the transfer of modern technology and the construction of large-scale concrete structures (Scott, 1998). Third, policy decisions that are far from the agreement, but close to certainty are the location of the water diversion sites in Sundarijal and Melamchi water supply projects. Finally, decisions on water transfer levy and PES are close to an agreement but uncertain during the time of the study. Other policy decisions in this category are the effectiveness of water treatment plants to supply adequate and safe drinking water. This finding is consistent with the literature that failure to recognize the complexity in the governance and management of water resources in Nepal's transboundary river basins led to the loss of ecosystem services, such as self-purification and groundwater recharge (Rademacher, 2011; Velz, 1984). As a result of the high modernist water resource development paradigm that oversimplified the complex problems, the ecosystem health of the two socioculturally important rivers, Bagmati and Bishnumati, has been deteriorated to an unacceptable level (Colopy, 2012; Dixit, 1997). 


\subsection{Hierarchical social space}

In centralized planning, each level of government has its areas of authority and responsibility, both geographically and substantively (Booher, 2005). This concept of authority also applies to the interbasin water transfers in Nepal that involve rural and urban municipalities, the state government, and the federal ministries. Substantively, as Scott (1998) puts it, hierarchical governance involves deep core beliefs about high modern state-building, such as technology transfer, large-scale water transfer and dam building. This finding is supported by previous research from Nepal and elsewhere that deliberative processes of public participation would allow alternative voices, discourses, beliefs and knowledge in the policy process (Clement et al., 2017).

In order to improve the ecosystem services of the Bagmati River Basin, the HPCIDBC principally aims to transform traditional hierarchical social spaces of decision making into a more distributed governance structures despite the practice of top-down decision making in practice. However, it is too early to come to a firm conclusion that these spaces are genuinely argumentative in the context of Nepal where social hierarchy often translates into hierarchical governance structures and policy processes. This finding is consistent with Hinsch's (2010) notion of argumentative dialogue in the collaborative governance and management of ecosystem services.

When the Melamchi Water Supply Project reached its most controversial stage during 2009, the dominant state actors were willing to collaborate with local and Indigenous communities to implement community development programmes. Conversely, local communities were also looking for opportunities to access the project funding and build their capacity for natural resource management and livelihood improvement. These findings substantiate the literature that collaborative governance institutions would bridge traditional hierarchies to implement localized actions with local or regional governments, and a local or regional government adopt collaborative governance to build capacity or access resources from federal or state agencies (Haapala et al., 2018; Margerum, 2011; Scott et al., 2017).

\subsection{Interdependence of management problems}

Local and Indigenous communities in the Melamchi Valley felt that they were historically neglected from the state. As a response to this policy gap, they had willingly collaborated with 
activist organizations from other regions, including the Kathmandu-based non-governmental organizations. The affinity to collaborate across places, spaces and policy sectors also applies to traditional natural resource management agencies, mainly when they cannot solve complex and interdependent problems alone (Booher, 2005). Managing multiple ecosystem services in Nepal's transboundary river basins is a challenging process as it involves decision making across various policy sectors. In our case, they include the WASH sector, agriculture and natural resources, urban farming, urban food forests, urban forests, and conservation of the holy rivers and the UNESCO World Heritage Sites and farmland. This finding substantiates the proposition that natural resource managers are more likely to collaborative to enhance their social capital and to solve problems that span across multiple policy sectors along the rural to the urban continuum (Margerum, 2011; Scott et al., 2017).

\subsection{Trust and commitment among stakeholders}

In the Melamchi Water Supply Project, after the project faced resistance, the adversarial relationships were transformed into cooperative ones through collaboration with local organizations, such as the Melamchi Concern Group, various local committees, and Kathmandubased non-governmental organizations. This finding confirms that social capital serves as glue within coalitions, brings together stakeholders with shared belief systems who would otherwise work independently of each other, and empowers minority stakeholders to establish collaborative relationships with those in power and authority (Hawkins et al., 2010). As articulated in the propositions about legitimacy (Table 2, conceptual framework), (Feiock, 2013; Scott et al., 2017), the Nepali state agencies worked with affected communities and well-reputed civil society organizations, albeit only in the later stages of the project to gain legitimacy of the large-scale interbasin water transfer.

\subsection{Miscommunication, controversy, and conflict}

Over time, collaborative governance, and management institutions in Nepal's rural to urban water supply transfer projects became relatively more diverse and inclusive of traditionally excluded stakeholders. This finding aligns with Booher's (2005) suggestion that water resource managers are increasingly required to deal with an array of stakeholders with their languages, values, perspectives, cognitive styles, and worldviews to transform adversarial relationships into 
cooperative ones. Concerning the propositions outlined in Table 2, natural resource managers prefer collaborative governance in the following two situations (Emerson et al., 2015; Scott et al., 2017): first, when the costs of managing ecosystem services are higher than the cost of implementing collaborative measures; and second, when they worry about the loss of power and influence (Emerson et al., 2015; Scott et al., 2017). Formation and funding of various social upliftment committees in the aftermath of civil society protests were instrumental to transform adversarial relationships between the state and the civil society. The civil society organizations and local communities, who were initially seen as contingent to the success of the project, were transformed into necessary collaborators in both water transfer projects This finding is consistent with the literature on building trust between state and civil society organizations (Friedman et al., 2002, 2006). In both water transfers in Nepal, the most salient regulatory policy instruments to facilitate the governance and management of water resources are the payment for environmental services and water transfer levy although their effectiveness is yet to be seen. This finding aligns with the literature on the governance and management of ecosystem services in Nepal and elsewhere (Adhikari et al., 2013; Bhatta et al., 2014; Engel et al., 2008; Pant et al., 2013).

\section{Conclusion}

Sustainability of water provisioning services in Nepal's transboundary river basins is at risk because the state has responded to looming water demand within the paradigm of high modernist state building using the available funding from multilateral aid agencies. The state interventions in the governance and management of ecosystem services focused primarily on the development of large-scale infrastructures, such as the tunnel and treatment plants without a genuine collaboration with the communities affected by water resource development. Hence, the novelty of this research lies in a systematic interrogation of the institutional aspects of water provisioning services, particularly collaborative governance structures and policy processes, that are not sufficiently addressed in the literature on governance and management of ecosystem services. This study concludes with the following five recommendations. First, community engagement should be initiated from the inception of a project. In the Melamchi Water Supply Project, collaborative governance institutions were established as a reactive measure to placate civil society protests

against the high modernist development interventions that could not sufficiently address social and environmental impacts. Second, to facilitate the process of community engagement, the state 
should move beyond the centralized, predictive planning and implementation of resource development projects and engage the affected communities and other stakeholders in project codesign and implementation. In Nepal's case, it was a missed opportunity to build regional and local capacity to govern and manage multiple ecosystem services. Third, water resource management projects should include multiple and interdependent sectors, actors, governance structures and policy processes. As the research results show, Nepal's water resource management challenges are interdependent and involve multiple policy sub-sectors: water, sanitation, hygiene, food, agriculture, natural resources, urban farming, food forests, urban forests, and conservation of the holy rivers and the UNESCO World Heritage Sites and farmland. Fourth, the state should proactively seek genuine participation of affected communities, activist groups, and nongovernmental organizations rather than transforming adversarial relationships as a reaction to outrageous downstream communications of policy concerns through street protests. It is time to transform the established culture of street protests to influence every policy process. Finally, a genuine collaboration with affected communities should be aimed at creating argumentative spaces where multiple stakeholders can safely engage in alternative propositions for governance and management of ecosystem services. These recommendations can be applied to the governance and management of multiple ecosystem services across the developing world to make effective policy decisions in rural to urban water transfers in transboundary river basins.

\section{References}

Acreman, M. (2016). Environmental flows-basics for novices. WIREs Water, 3(5), 622-628. doi: $10.1002 /$ wat 2.1160

ADB. (2013). Initial Environmental Examination: Pre-Investigative Works for Feasibility Study NEP: Bagmati River Basin Improvement Project. Kathmandu, Nepal: Asian Development Bank.

Adhikari, B., \& Agrawal, A. (2013). Understanding the Social and Ecological Outcomes of PES Projects: A Review and an Analysis. Conservation and Society, 11(4), 359-374.

Agrawal, A., \& Lemos, M. C. (2007). A Greener Revolution in the Making? Environmental Governance in the 21st Century. Environment, 49(5), 37-45.

Ananda, J., \& Proctor, W. (2013). Collaborative approaches to water management and planning: An institutional perspective. Ecological Economics, 86, 97-106.

Ansell, C., \& Gash, A. (2008). Collaborative Governance in Theory and Practice. Journal of Public Administration Research and Theory, 18, 543-571.

Asah, S., \& Blahna, D. J. (2012). Practical Implications of Understanding the Influence of Motivations on Commitment to Voluntary Urban Conservation Stewardship. Conservation Biology, 27(4), 866875. 
Babel, M. S., Pandey, V. P., Rivas, A. A., \& Wahid, S. M. (2011). Indicator-Based Approach for Assessing the Vulnerability of Freshwater Resources in the Bagmati River Basin, Nepal. Environmental Management, 48, 1044-1059.

Beetham, D. (Ed.). (1991). The Legitimation of Power: Issues in Political Theory (2nd edition ed.). England: Palgrave Macmillan.

Bhatta, L. D., van Oort, B. E. H., Rucevska, I., \& Baral, H. (2014). Payment for ecosystem services: possible instrument for managing ecosystem services in Nepal. International Journal of Biodiversity Science, Ecosystem Services \& Management, 10(4), 289-299.

Bhattarai, B. R., Wright, W., Poudel, B. S., Aryal, A., Yadav, B. P., \& Wagle, R. (2017). Shifting paradigms for Nepal's protected areas: history, challenges and relationships. Journal of Mountain Science, 14(5), 964-979. doi: 10.1007/s11629-016-3980-9

Bhattarai, M., Pant, D., \& Molden, D. (2005). Socio-economics and hydrological impacts of Melamchi intersectoral and interbasin water transfer project, Nepal. Water Policy, 7, 163-180.

Booher, D. E. (2005). Collaborative Governance Practices and Democracy. National Civic Review, 93(4), 32-46.

Booher, D. E., \& Innes, J. E. (2010). Governance for Resilience: CALFED as a Complex Adaptive Network for Resource Management. Ecology and Society, 15(3), 35.

Borradaile, Green, M., Moon, L., Robinson, P., \& Tait, A. (1977). Langtang National Park Management Plan 1977-1982. Kathmandu, Nepal and Durham, UK: National Parks and Wildlife Conservation Project, National Parks and Wildlife Conservation Nepal and Durham University Himalayan Expedition, UK.

Bramston, P., Pretty, G., \& Zammit, C. (2011). Assessing Environmental Stewardship Motivation. Environment and Behavior, 43(6), 776-788.

Brooks, D. B. (2002). Water: Local Level Management. Ottawa, Ontario, Canada: International Development Research Centre (IDRC).

Cameron, J., \& Abouchar, J. (1991). The Precautionary Principle:A Fundamental Principle of Law and Policy for the Protection of the Global Environment. Policy for the Protection of the Global Environment, 14(1), 1-27.

CBS. (2014). Multiple Indicator Cluster Survey 2014. Kathmandu, Nepal: Central Bureau of Statistics (CBS), Government of Nepal.

Clark, J. R. A., \& Semmahasak, C. (2013). Evaluating Adaptive Governance Approaches to Sustainable Water Management in North-West Thailand. Environmantal Management, 51(4), 882-896.

Clement, F., Suhardiman, D., \& Bharati, L. (2017). IWRM discourses, institutional Holy Grail and water justice in Nepal. Water Alternatives, 10(3), 870-887.

Colopy, C. (2012). Dirty, Sacred River: Confronting South Asia's Water Crisis. New York: Oxford University Press.

Creswell, J. W., \& Clark, V. L. P. (2018). Designing and Conducting Mixed Methods Research, Third Edition. London, UK: Sage Publications.

Dhital, Y. P., Qiuhong, T., \& Jiancheng, S. (2013). Hydroclimatological changes in the Bagmati River Basin, Nepal. Journal of Geographical Sciences, 23(4), 612-626.

Dietz, T., Ostrom, E., \& Stern, P. C. (2003). The Struggle to Govern the Commons. Science, $32(12$ December 2003), 1907-1912.

Dixit, A. (1997). Inter-Sectoral Water Allocation: A case study in Upper Bagmati Basin. In R. Pradhan, F. von Belda-Beckmann, K. von Benda-Beckmann, H. L. J. Spiertz, S. S. Khadka \& K. A. Haq (Eds.), Water Rights, Conflict and Policy (pp. 195-220). Colombo, Sri Lanka: International Water Management Institute (IWMI).

Domènech, L., March, H., \& Sauríc, D. (2013). Contesting large-scale water supply projects at both ends of the pipe in Kathmandu and Melamchi Valleys, Nepal. Geoforum, 47, 22-31.

Dyson, M., Bergkamp, G., \& Scanlon, J. (Eds.). (2003). Flow: The Essentials of Environmental Flows. Gland, Switzerland and Cambridge, UK: IUCN. 
Emerson, K., \& Nabatchi, T. (2015). Collaborative Governance Regimes. Washington, DC: Georgetown University Press.

Emerson, K., Nobatchi, T., \& Balogh, S. (2011). An Integrative Framework for Collaborative Governance. Journal of Public Administration Research and Theory 21(1), 1-29.

Engel, S., Pagiola, S., \& Wunder, S. (2008). Designing payments for environmental services in theory and practice: An overview of the issues. Ecological Economics, 65, 663-674.

EPA. (2009). Goal 5 Environmental Stewardship. Washington, DC: United States Environmental Protection Agency (EPA).

Faunce, T., Murray, K., Nasu, H., \& Bowman, D. (2008). Sunscreen Safety: The Precautionary Principle, The Australian Therapeutic Goods Administration and Nanoparticles in Sunscreens. Nanoethics, 2, 231-240.

Feiock, R. C. (2013). The Institutional Collective Action Framework. The Policy Studies Journal, 41, 397-425.

Ferreyra, C., de Loe, R. C., \& Kreutzwiser, R. D. (2008). Imagined communities, contested watersheds: Challenges to integrated water resources management in agricultural areas. Journal of Rural Studies, 24, 304-321.

Folke, C. (2006). Resilience: The emergence of a perspective for social-ecological systems analyses Global Environmental Change, 16(3), 253-267.

Folke, C., Hahn, T., Olsson, P., \& Norberg, J. (2005). Adaptive Governance of Social-Ecological Systems. Annual Reviews Environmental Resources, 30, 441-4473.

Foster, K. R., Vecchia, P., \& Repacholi, M. H. (2000). Science and the Precautionary Principle. Science of The Total Environment, 288(5468). doi: 10.1126/science.288.5468.979

Fox, J., Yonzon, P., \& Podger, N. (1996). Mapping Conflicts Between Biodiversity and Human Needs in Langtang National Park, Nepal. Conservation Biology, 10(2), 562-569.

Freeman, R. E. (2010). Strategic Management: A Stakeholder Approach. Cambridge: Cambridge University Press.

Friedman, A. L., \& Miles, S. (2002). Developing Stakeholder Theory. Journal of Management Studies, $39,1-21$.

Friedman, A. L., \& Miles, S. (2006). Stakeholder: Theory and Practice. Oxford: Oxford University Press.

Funtowictz, S. O., \& Ravetz, G. R. (1993). Science for the post-normal age. Futures, 25(7), 739-755.

Gallopin, G. C. (2006). Linkages between vulnerability, resilience and adaptive capacity. Global Environmental Change, 16(3), 293-303.

GoN. (2019). Bagmati River Basin Improvement Project Retrieved October 2, 2019, from http://www.brbip.gov.np/

Goode, W. J. (1997). Rational Choice Theory. The American Sociologist, 28(2), 22-41.

Gray, B., \& Purdy, J. (2018). Collaborating for Our Future: Multistakeholder Partnerships for Solving Complex Problem. Oxford, UK: Oxford University Press.

Gunderson, L., Holling, C. S., \& Light, S. S. (1995). Barriers and bridges to the renewal of ecosystems and institutions. New York: Columbia University Press.

Haapala, J., \& White, P. ( 2018). Development through bricoleurs: Portraying local personnel's role in the implementation of water resources development in rural Nepal. Water Alternatives, 11(3), 979998.

Hawkins, R. L., \& Maurer, K. (2010). Bonding, Bridging and Linking: How Social Capital Operated in New Orleans following Hurricane Katrina. British Journal of Social Work, 40, 1777-1793.

Hill, M., \& Hupe, P. (2006). Implementing Public Policy Oliver's Yard 55 City Road, London ECIY ISP: Sage Publication Ltd.

Himmelman, T. (2001). On Coalitions and the Transformation of Power Relations: Collaborative Betterment and Collaborative Empowerment. American Journal of Community Psychology, 29(2), 277-284.

Hinsch, W. (2010). Justice, legitimacy, and constitutional rights. Critical Review of International Social and Political Philosophy, 13(1), 39-54. doi: https://doi.org/10.1080/13698230903326240 
Holling, C. S. (1978). Adaptive environmental assessment and management. Laxenburg, Austria: International Institute for Systems Analysis (IISA).

Holling, C. S. (1996). Engineering resilience versus ecological resilience. In P. Schulze (Ed.), Engineering Within Ecological Constraints (pp. 31-44). Washington DC: National Academy Press.

Homans, G. (1961). Social Behaviour: Its Elimentary Forms. London: Routledge and Kegan Paul.

Hornbaker, M. H., \& Cullen, A. (2003). The Precautionary Principle in Practice: Applying the Ashford Framework to Technological Risk. Human and Ecological Risk Assessment, 9(3), 789-810.

Innes, J. E., \& Booher, D. E. (2018). Planning with Complexity: An Introduction to Collaborative Rationality for Public Policy. New York: Taylor and Francis.

Innes, J. E., Booher, D. E., \& Di Vittorio, S. (2011). Strategies for Megaregion Governance: Collaborative Dialogue, Networks and Self-Organization. Journal of the American Planning Association, 77(1), 55-67.

Keune, H., Dendoncker, N., Popa, F., Sander, J., Kampelmann, S., Boeraeve, F., . . Verboven, J. (2015). Emerging ecosystem services governance issues in the Belgium ecosystem services community of practice. Ecosystem Services, 16, 212-219. doi: https://doi.org/10.1016/j.ecoser.2015.06.001

Khadka, R. B., \& Khanal, A. B. (2008). Environmental Management Plan (EMP) for Melamchi Water Supply Project. International Journal Environment Research, 2(1), 87-96.

Kiser, L. L., \& Ostrom, E. (1982). The Three Worlds of Action: A Metatheoritical Synthesis of Institutional Approaches. In E. Ostrom (Ed.), Strategic Political Inquiry (pp. 179-222). Beverley Hills, CA: Sage.

Kreutzwiser, R., Loë, R. d., Imgrundb, K., Conboy, M. J., Hugh Simpsond, \& Plummere, R. (2011). Understanding stewardship behaviour: Factors facilitating and constraining private water well stewardship. Journal of Environmental Management, 92, 1104-1114.

KUKL. (2016). Annual Report: Kathmandu Upatyaka Khanepani Limited 2016. Kathmandu, Nepal.

Kunwar, K. J. (2008). Payment for Environmental Services in Nepal: A Case Study of Shivapuri Nagarjun National Park, Kathmandu, Nepal. The Initiation, 2(1), 64-72.

Liarakou, G., Kostelou, E., \& Gavrilakis, C. (2011). Environmental volunteers: factors influencing their involvement in environmental action. Environmental Education Research, 17(5), 651-673.

Linnenluecke, M. K., Verreynne, M., de Villiers Scheepers, M. J., \& Venter, C. (2017). A review of collaborative planning approaches for transformative change towards a sustainable future. Journal of Cleaner Production, 142, 3212-3224. doi: doi:10.1016/j.jclepro.2016.10.148

Mann, C., Loft, L., \& Hansjürgens, B. (2015). overnance of Ecosystem Services: Lessons learned for sustainable institutions. Ecosystem Services, 16, 275-281. doi: http://dx.doi.org/10.1016/j.ecoser.2015.11.003

Marambio-Jones, C., \& Hoek, E. M. V. (2010). A review of the antibacterial effects of silver nanomaterials and potential implications for human health and the environment. Journal of Nanoparticle Research 12(5), 1531-1551.

Margerum, R. D. (2011). Beyond Consensus: Improving Collaborative Planning and Management. Cambridge, MA: MIT Press.

Maskey, N. (2008). Investing in Ecosystem Services: Opportunities and Challenges for Shivapuri National Park, Nepal. MSc, Lund University, Lund, Sweden.

MDG. (2013). The Millennium Development Goals Report, United Nations Deputy Secretary-General's Call to Action on Sanitation. New York: United Nations Headquarters.

MEA. (2005). Millennium Ecosystem Assessment Wetland and Water Synthesis : Ecosystem and Human Well-being. Washington, D.C.: World Resources Institute.

Morrison, K., \& FitzGibbon, J. E. (2014). Adaptive Governance of Dynamic Social-Ecological Systems: The case of the Ontario Environmental Farm Plan Agroecology and Sustainable Food Systems, 38(4), 378-409.

Olsson, P., Folke, C., \& Berkes, F. (2004). Adaptive Comanagement for Building Resilience in SocialEcological Systems. Environmental Management, 34(1), 75-90. 
Ostrom, E. (1998). A Behavioral Approach to the Rational Choice Theory of Collective Action:Presidential Address, American Political Science Association. The American Political Science Review 92(1), 1-22.

Ostrom, E. (2010). Beyond Markets and States: Polycentric Governance of Complex Economic Systems. American Economic Review, 100, 641-672.

Pant, D., Bhattarai, M., \& Basnet, G. (2008). Implications of Bulk Water Transfer on Local Water Management Institutions: A Case Study of the Melamchi Water Supply Project in Nepal. Collective Action and Property Rights, 78.

Pant, K. P., \& Rasul, G. (2013). Role of Payment for Environmental Services in Improving Livelihoods and Promoting Green Economy: Empirical Evidence from a Himalayan Watershed in Nepal. Journal of Environmental Professionals Sri Lanka, 2(1), 1-13.

Parkes, M. W., Morrison, K. E., Bunch, M. J., \& Venema, H. D. (2008). Ecohealth and watersheds: Ecosystem Approaches to Re-integrate Water Resources Management with Health and Wellbeing. Winnipeg, Canada: Network for Ecosystem Sustainability and Health and International Institute for Sustainable Development.

Peh, K. S. H., Thapa, P., Basnyat, M., Balmford, A., Bhattarai, G. P., Bradbury, R. B., . . Merriman, J. C. (2016). Synergies between biodiversity conservation and ecosystem service provision: Lessons on integrated ecosystem service valuation from a Himalayan protected area, Nepal. Ecosystem Services, 22 (part B), 359-369. doi: doi:10.1016/j.ecoser.2016.05.003

Persson, E. (2016). What are the core ideas behind the Precautionary Principle? Science of the Total Environment, 557-558, 134-141.

Primmer, E., Jokinen, P., Blicharska, M., Barton, D. N., Bugter, R., \& Potschin, M. (2015). Governance of Ecosystem Services: A framework for empirical analysis. Ecosystem Services, 16, 158-166. doi: https://doi.org/10.1016/j.ecoser.2015.05.002

Rademacher, A. M. (2011). Reigning the River: Urban Ecologies and Political Transformation in Kathmandu. Durham: Duke University Press.

Richter, B. (2008). Water Stewardship Certification: Promoting Social Responsibility and Environmental Sustainability. Journal of American Water Works Association, 100(12), 28-34.

Ryan, R. L., Rachel , K., \& Robert, E. G. (2001). Predicting Volunteer Commitment in Environmental Stewardship Programmes. Journal of Environmental Planning and Management, 44(5), 629-648.

Sabatier, P. A., \& Weible, C., M. (2007). The Advocacy Coalition Framework: Innovations and Clarifications. In P. A. Sabatier (Ed.), Theories of the Policy Process. Cambridge, MA: Westview Press.

Schleyer, C., Görg, C., Hauck, J., \& Winkler, K. J. (2015). Opportunities and challenges for mainstreaming the ecosystem services concept in the multi-level policy-making within the EU. Ecosystem Services, 16, 174-181. doi: https://doi.org/10.1016/j.ecoser.2015.10.014

Schultz, L., Duit, A., \& Folke, C. (2011). Participation, Adaptive Co-management, and Management Performance in the World Network of Biosphere Reserves. World Development 39(4), 662-671.

Schultz, P. W. (2001). The structure of environmental concern: Concern for self, other people, and the biosphere. Journal of Environmental Psychology, 21, 327-339.

Scott, J. (2000). Rational Choice Theory In G.Browning, A.Halcli \& F.Webster (Eds.), From Understanding Contemporary Society: Theories of The Present. London, UK: Sage Publications.

Scott, J. C. (1998). Seeing like a State: How Certain Schemes to Improve the Human Condition have Failed. New Haven, CT: Yale University Press.

Scott, T. A., \& Thomas, C. W. (2017). Unpacking the Collaborative Toolbox: Why and When Do Public Managers Choose Collaborative Governance Strategies? The Policy Studies Journal, 45(1), 191214.

Sharp, L., McDonald, A., Sim, P., Knamiller, C., Sefton, C., \& Wong, S. (2011). Positivism, postpositivism and domestic water demand: interrelating science across the paradigmatic divide. Transactions of the Institute of British Geographers 36, 501-515. 
Shrestha, P. L. (1998). Conservation and Management of Watershed Region by Nepalese Women Leading to Enhancement of Water Potential. International Journal of Water Resource Development, 14(4), 513-525.

Sleat, M. (2015). Justice and Legitimacy in Contemporary Liberal Thought: A Critique. Social Theory and Practice, 41(2), 230-252. doi: 10.5840/soctheorpract201541213

SNNP. (2017). My National Park, Annual Report 2016-2017. Bhudanilkantha, Kathmandu, Nepal: Shivapuri Nagarjun National Park Office, Department of National Parks and Wildlife Conservation, Ministry of Forests and Soil Conservation.

SNNP. (nd). A study report on the consumption of drinking water resources in the Shivapuri Nagarjun National Park [in Nepali]. Budhanilkantha, Kathmandu Nepal: Shivapuri Nagarjun National Park Office, Department of National Parks and Wildlife Conservation, Ministry of Forests and Soil Conservation.

Stacey, R. D. (2002). Strategic Management and Organizational Dynamics: The Challenges of Complexity (Third Edition ed.). Harlow: Prentice Hall.

Stern, P. C., Dietz, T., \& Ostrom, E. (2002). Research on the Commons: Lessons for Environmental Resource Managers. Environmental Practice, 4(2), 61-64.

Stewart, R. B. (2002). Environmental Regulatory Decision Making Under Uncertainty. Research in Law and Economics, 20, 76.

Summers , J. R., Plummer, R., \& FitzGibbon, J. (2008). Accounting precautionary measures in agriculture through pathway analysis: the case of the Environmental Farm Plan. International Journal of Agricultural Resources, Governance and Ecology, 7(6), 437-449.

Udmale, P., Ishidaira, H., Thapa, B. R., \& Shakya, N. M. (2016). The Status of Domestic Water Demand: Supply Deficit in the Kathmandu Valley, Nepal. Water, 8(196), 5-9.

United Nations. (2015). Transforming our World: The 2030 Agenda for Sustainable Development. New York: United Nations.

Velz, C. J. (1984). Applied Stream Sanitation (Second ed.). New York: A Wiley-Interscience Publication.

Wester, P., Mishra, A., Mukherji, A., \& Shrestha, A. B. (Eds.). (2019). The Hindu Kush Himalaya Assessment-Mountains, Climate Change, Sustainability and People. Switzerland AG, Cham: Springer Nature.

WHO. (2017). Progress on drinking water, sanitation and hygiene: 2017 update and SDG baselines. Geneva: World Health Organization (WHO) and the United Nations Children's Fund (UNICEF), 2017. 